УДК 378.011.3-057.87:373.3:316.72

\title{
ТЕТЯНА АТРОЩЕНКО
}

Мукачівський державний університет

\section{РЕАЛІЗАЦІЯ ПОЛІКУЛЬТУРНОГО КОМПОНЕНТА У ПРОФЕСІЙНІЙ ПІДГОТОВЦІ МАЙБУТНІХ УЧИТЕЛІВ ПОЧАТКОВИХ КЛАСІВ}

У статті обгрунтовано шляхи реалізації полікультурного компонента у професійній підготовці майбутніх учителів початкових класів. Охарактеризовано полікультурний компонент професійнопедагогічної підготовки майбутніх учителів початкових класів та виділено його основні структурні елементи. Представлено навчальну дисципліну «Теорія і практика формування міжетнічної толерантності майбутніх учителів початкової школи» та ії значення у полікультурній підготовці студентів-магістрів спеціальності 013 «Початкова освіта». Рекомендовано інноваційні методи і форми навчальної роботи, які сприяють підготовці полікультурного фахівця початкової ланки освіти.

Ключові слова: вчитель початкових класів, діалог культур, культура міжнаціонального спілкування, міжетнічна толерантність, полікультурний компонент, полікультурна освіта, професійна підготовка, ціннісні орієнтації

Постановка проблеми та її зв'язок із важливими науковими та практичними завданнями. Сучасні держави - це полікультурні співтовариства. Цьому сприяють процеси інтеграції, глобалізації та зростаюча мобільність населення. Відповідно, підвищується інтенсивність взаємодії мов, культур, звичаїв, традицій, гармонійний розвиток яких повинен відбуватися на принципах рівноцінності та рівноправності. Прагнення особистості до взаємодії з людьми, які належать до інших культурних шарів, стає необхідною умовою успішної професійної діяльності фахівця в сучасних умовах, його соціалізації після закінчення закладу вищої освіти. Необхідність толерантної поведінки, спрямованої на конструктивну взаємодію з іншим, що виражається у свідомому придушенні почуття неприйняття іншого, доводить необхідність використання різноманітних методик та підходів у процесі формування та розвитку полікультурного компонента в процесі навчання у закладах вищої освіти, визначаючи вектор розвитку міжетнічних взаємин у майбутніх учителів початкових класів.

Аналіз останніх досліджень і публікацій. Теоретичні положення підготовки майбутнього вчителя у закладах вищої освіти відображено у працях В.Андрущенка, I. Беха, О. Глузмана, О. Дубасенюк, В. Євтуха, І. Зязюна, Н. Кічук, О. Кондратьєвої, Н. Кузьміної, Л. Пєхоти, О.Савченко, Л. Сущенко, Л. Хомич та ін. У контексті визначеної проблеми актуальними є праці вітчизняних та зарубіжних науковців 3 питань полікультурної освіти (Д. Бенкс, Л. Волик, О. Грива, О.Гуренко, Г. Дмитрієв, Т. Коваль, В. Матіс, Д. Міттер, С. Нієто, К. Юр'єва, Н. Якса та ін.). Незважаючи на наявні різноаспектні дослідження, вважаємо за необхідне більш грунтовно вивчити проблему професійної підготовки вчителя початкових класів у закладах вищої освіти в контексті полікультурної освіти.

Мета статті - обгрунтувати шляхи реалізації полікультурного компонента у професійній підготовці майбутніх учителів початкових класів.

Виклад основного матеріалу дослідження. Сьогодні стаємо свідками активного прояву тенденцій, що відображають прагнення етносів відродити, зберегти і розвивати свої національні традиції, мову і затвердити сучасну культуру на особистісному та груповому рівнях. Міжкультурний діалог в полікультурному середовищі можливий тільки тоді, коли кожен з його суб'єктів, усвідомлюючи свою унікальність і самобутність, розуміє та приймає цінності іншого партнера. Основними завданнями розвитку вітчизняної вищої освіти, поряд з розвитком власної національної культури, вважаємо виховання студентів - майбутніх учителів початкових класів у дусі діалогу культур, миру та поваги до усіх народів, викорінюючи існуючі в побуті негативні уявлення про людей інших національностей, рас, релігій тощо.

Полікультурна освіта, за визначенням О. Гриценко та Н. Гончаренко, - це відповідна побудова навчальних програм, підручників, методів навчання, а також системи навчальних закладів, яка б забезпечувала досягнення таких основних цілей: забезпечення законних прав та задоволення освітніх і культурних потреб національних (етнічних), мовних, культурних меншин; формування у молодих громадян України всіх національностей повноцінних уявлень про етнічне й мовно-культурне різноманіття сучасного українського суспільства та внесок різних етнічних груп та народів-сусідів у нашу історію й культуру, знань про мову й культури великих і малих народів, що населяють Україну, переконаності в цінності культурного різноманіття та плюралізму; виховання толерантності, здатності до міжетнічного й міжкультурного діалогу; поєднання виховання лояльних, патріотичних громадян демократичної України, панування етноцентричної моделі національної культури й самосвідомості (Гончаренко, 2007, с. 94).

Полікультурна освіта вирішує ряд практичних та навчально-виховних проблем: мирну і плідну взаємодію різних культур у просторі закладу вищої освіти, адже кожний студент привносить в нього культуру своїх батьків і друзів, етнічної групи і соціального шару, до якого належить; збагачення, культурна 
децентрація картини світу майбутнього фахівця, по можливості звільнення її від стереотипів дискримінації щодо інших етнічних груп; розвиток критичного мислення в ході усвідомлення багатовимірності суспільної реальності, її поліфонічності та різноманітності, допустимості альтернативних точок зору, логік міркування, мов самовираження; обробка навичок ведення діалогу і продуктивності обміну думками; чуйне ставлення до стану іншого, терпимості до «інакшості», що є принциповим для процесів соціальної солідарності, формування міжетнічної толерантності майбутніх учителів початкових класів.

О. Джуринський вважає, що одним із способів організації полікультурного виховання є забезпечення культурологічної спрямованості мовної освіти і введення полікультурного компонента у різні навчальні дисципліни. Провідним при цьому залишається двомовне і багатомовне навчання (рідна мова, мова домінуючого етносу, іноземні мови), яке не тільки дозволяє здійснювати процес комунікації, але i долучитися до різних способів мислення, відчуттів, поведінки (Джуринський, 2002, с. 95).

Погоджуємося з О. Кондратьєвою, що в основу кардинальних змін у системі професійно-педагогічної підготовки майбутніх учителів покладено методологічні засади, які визначають роль педагога як суб'єкта полікультурного середовища. Ця роль випливає із провідних філософських ідей стосовно сучасних світових концепцій, що поширюються в освітньому просторі: концепція глобалізації, що передбачає відповідність педагогічної освіти особливостям глобального розвитку, об'єднання кращих інтелектуальних ресурсів, міжнародне співробітництво в освітній сфері, побудоване на засадах діалогу і взаємодії культур; концепції регіоналізації (локалізації) відповідності педагогічної освіти регіональним полікультурним особливостям; положення про розвиток культур корінних народів та етнічних груп; розвиток локального партнерства міжкультурної взаємодії в освіті; відповідність навчальних програм педагогічної підготовки майбутніх учителів потребам регіону; концепція індивідуалізації, спрямована на посилення у майбутніх учителів мотивації, ініціативи, творчості в навчанні; їх залучення до світової та національної спадщини; розвиток ціннісних орієнтацій, знань, технологій, норм поведінки; розвиток особистісного потенціалу майбутнього педагога в соціальному, культурному, освітньому аспектах (Кондратьєва, 2017, с. 14).

Полікультурний компонент розглядаємо як одну із складових професійно-педагогічної підготовки майбутніх учителів початкових класів. Його зміст реалізується у його сфері діяльності, направлений на розвиток професійних умінь і навичок, ціннісно-орієнтаційної основи особистості та сприяє формуванню готовності майбутнього фахівця до полікультурної взаємодії.

Склад полікультурного компонента професійно-педагогічної підготовки включає в себе сукупність взаємопов'язаних елементів як зовнішнього (етнокультурного, соціокультурного, міжкультурного), так і внутрішнього (світоглядного) планів, що визначають зміст професійно-педагогічної підготовки студентів на основі введення в навчально-виховний процес теоретичного і практичного матеріалу, що характеризується полікультурною спрямованістю.

Відповідно до такого розуміння полікультурного компонента професійно-педагогічної підготовки виділяємо у ньому такі основні структурні елементи: етнокультурний - сприяє взаєморозумінню людей на основі етнокультурних цінностей, спрямований на формування культури міжнаціональних відносин за допомогою вивчення особливостей мови, культури, звичаїв, традицій; соціокультурний - відображає вплив суспільно-історичних процесів на потреби та розвиток національної освіти, культури і, на цій основі, формування духовних цінностей особистості того чи іншого етносу; міжкультурний - передбачає комунікативну взаємодію представників різних культур, розвиток культури міжнаціонального спілкування.

Інтегральна компетентність, яка $€$ складовою програмних компетентностей спеціальності 013 «Початкова освіта» $\epsilon$ передбачає здатність компетентно розв'язувати різноаспектні комплексні задачі і проблеми в галузі початкової освіти та вищої школи, керуючись принципами толерантної комунікації, культурної і міжкультурної взаємодії, творчої, креативної й інноваційної професійної діяльності у виробничих ситуаціях, що характеризуються невизначеністю умов і вимог. Відповідно, одним із провідних шляхів реалізації полікультурного компонента у професійній підготовці майбутніх учителів початкових класів вважаємо розвиток інтегрального підходу до вивчення певних тем дисциплін циклу професійноорієнтованої підготовки та спеціальних дисциплін; використання в процесі лекційних та практичних занять, в ході педагогічної практики та у позааудиторній роботі інформації полікультурного змісту, акцентуючи увагу студентів на важливості толерантного співіснування у багатоетнічному середовищі, позитивних тенденціях мирної співпраці та негативних наслідках національних, релігійних та інших конфліктів.

До прикладу, в Мукачівському державному університеті студенти спеціальності 013 «Початкова освіта» ОС «Магістр» вивчають дисципліни «Початкова школа Закарпаття», «Університетська освіта в Україні та країнах Східної Європи: історія і сучасність», «Теорія і практика формування міжетнічної толерантності майбутніх учителів початкової школи», які сприяють формуванню полікультурної компетентності майбутнього вчителя початкових класів, знайомлять із специфікою освіти багатонаціонального Закарпатського краю, традиціями та досвідом підготовки фахівців в університетах Східної Європи.

Метою розробленого нами курсу «Теорія і практика формування міжетнічної толерантності майбутніх учителів початкової школи» $\epsilon$ сприяння засвоєнню студентами на міждисциплінарній основі найважливіших понять і категорій полікультурної освіти, технологій діагностики і формування міжетнічної 
толерантності, полікультурного виховання і оцінки реальних педагогічних ситуацій в умовах полікультурної взаємодії (Атрощенко, 2017).

Завдання курсу: ознайомлення з основними науковими концепціями міжетнічної толерантності; розвиток компетенцій і навичок формування основ міжетнічної толерантності в умовах поліетнічного регіону; використання науково-обгрунтованих методів і сучасних інформаційних технологій в організації власної професійної діяльності в умовах поліетнічного регіону; формування умінь і навичок, необхідних для діагностики міжетнічної толерантності на різних рівнях функціонування; формування умінь і навичок, необхідних для практичного використання тренінгових програм, направлених на формування міжетнічної толерантності у різних вікових та етнічних групах; участь в розробці індивідуальних траєкторій полікультурного розвитку; створення умов для повноцінного навчання, виховання, взаємодії і спілкування в багатонаціональному колективі; організація спільної діяльності і міжособистісної взаємодії суб'єктів полікультурного освітнього середовища.

Дисципліна містить такі теми: «Передумови виникнення і розвитку полікультурної освіти в світі», «Полікультурна освіта як фактор формування толерантних стосунків», «Етнопедагогічна компетентність в полікультурній освіті», «Поняття «толерантність» та «міжетнічна толерантність»», «Науково-теоретичні основи формування міжетнічної толерантності майбутнього вчителя початкової школи в процесі професійної підготовки», «Формування міжетнічної толерантності майбутніх вчителів початкової школи», «Підготовка майбутнього вчителя до виховання міжетнічної толерантності та культури міжнаціонального спілкування в учнів початкової школи», «Специфіка взаємодії майбутнього вчителя початкової школи 3 батьками в умовах поліетнічного середовища».

На початку і у підсумках вивчення курсу студенти - магістри (30 осіб) мали змогу продіагностувати власний рівень міжетнічної толерантності (МТ). На початку вивчення курсу ми отримали такі дані: високий рівень МТ - 10 студентів; середній рівень - 12 ; низький рівень - 8. По завершенню вивчення курсу ми відмітити позитивну тенденцію зростання рівня міжетнічної толерантності: високий рівень МТ - 14 студентів; середній рівень - 16; низький рівень - 0 .

На нашу думку, цьому сприяло те, що окрім звичних лекцій, семінарів, бесід, круглих столів тощо, ми здійснювали системне застосування таких інноваційних методів і форм навчальної роботи як:

- дискусії з приводу різноаспектних тем розвитку полікультурного суспільства, міжнаціональних та інших суперечних проблем;

- постановка проблемних задач і ситуацій та організація їх вирішення студентами у колективній, груповій та індивідуальній діяльності;

- організація і стимулювання індивідуальної роботи студентів з архівними документами, науковою літературою та матеріалами преси, ознайомлення з якими поглибить розуміння студентами проблем, які виникають у культурно-освітньому та громадському житті представників різних етнічних, релігійних та інших спільнот полікультурної України;

- ознайомлення з європейським та світовим досвідом у вирішенні питань полікультурної освіти та виховання, ефективними шляхами запобігання та вирішення міжетнічних конфліктів, специфікою роботи із біженцями, мігрантами, переселенцями та іншими проблемами, які виникають у мультикультурному суспільстві;

- моделювання різноаспектних міжетнічних ситуацій засобами ділової чи рольової гри, кейс-методу, мозкової атаки і т.д.

Слід також зазначити, що важливе місце в полікультурній підготовці майбутніх учителів початкових класів посідає педагогічна практика, самостійна та професійно спрямована позааудиторна робота, науководослідна діяльність студентів у ракурсі полікультурної проблематики.

Висновки. Запровадження полікультурної освіти майбутніх учителів початкових класів у закладах вищої освіти нами розглянуто в контексті реалізації полікультурного компонента професійної підготовки цих фахівців. Одним із оптимальних шляхів реалізації полікультурного компонента у професійній підготовці майбутніх учителів початкових класів вважаємо розвиток інтегрального підходу до вивчення певних тем у дисциплінах циклу професійно-орієнтованої підготовки та спеціальних дисциплін.

\section{Список використаних джерел}

Атрощенко,Т. О. (2017). Теорія і практика формування міжетнічної толерантності майбутніх вчителів початкової иколи: методичні рекомендації до вивчення спецкурсу для студентів спеціальності 013 «Початкова освіта» освітнього ступеня магістр. Мукачево : МДУ

Гончаренко, Н. А., Зубко, А.М. \& Кузьменко В. В. (2007). Розвиток полікультурної компетентності педагогів загальноосвітніх навчальних закладів: навчальний посібник. Кузьменко В. В. (Ред.). Херсон: РІПО.

Джуринский, А. Н. (2002). Поликультурное воспитание: сущность и перспективы развития. Педагогика, 10, 9396.

Кондратьєва, О. М. (2017). Формування полікультурної компетентності майбутніх учителів початкової школи (на засадах лінгвокраӥнознавчого підходу) (автореф. дис. канд. пед. наук : 13.00.04). Київ.

\section{References}

Atroshchenko, T. O. (2017). Teoriia i praktyka formuvannia mizhetnichnoi tolerantnosti maibutnikh vchyteliv pochatkovoi shkoly [Theory and practice of forming interethnic tolerance for future teachers of elementary school]: 
metodychni rekomendatsii do vyvchennia spetskursu dlia studentiv spetsialnosti 013 «Pochatkova osvita» osvitnoho stupenia mahistr. Mukachevo: MDU [in Ukrainian].

Honcharenko, N. A. (2007). Rozvytok polikulturnoi kompetentnosti pedahohiv zahalnoosvitnikh navchalnykh zakladiv [Development of multicultural competence of teachers of general educational institutions]: navchalnyi posibnyk. Kherson: RIPO [in Ukrainian].

Dzhurinskij A. N. (2002). Polikul'turnoe vospitanie: sushchnost' i perspektivy razvitiya [Polycultural education: the nature and development prospects]. Pedagogika (Vol. 10, p. 93-96). [in Russian].

Kondratieva O.M. (2017). Formuvannia polikulturnoi kompetentnosti maibutnikh uchyteliv pochatkovoi shkoly (na zasadakh linhvokrainoznavchoho pidkhodu) [Formation of multicultural competence of future teachers of elementary school (on the basis of the linguistic-ethnographic approach)] dys. kand. ped. nauk: 13.00.04. Kyiv [in Ukrainian].

\section{ATROSHCHENKO T.}

Mukachevo State University, Ukraine

\section{REALIZATION OF THE MULTICULTURAL COMPONENT IN PROFESSIONAL PREPARATION OF FUTURE TEACHERS OF PRIMARY SCHOOL}

The article has substantiated the ways of implementing a multicultural component in the training of future primary school teachers. We have consider polycultural component as one of the components of vocational and pedagogical training of future teachers of primary school. Its content is realized in its field of activity, aimed at the development of professional skills and values, value-orientation basis of personality and promotes formation of readiness of the future specialist for multicultural interaction.

The composition of the multicultural component of vocational and pedagogical training includes a set of interrelated elements as external (ethno-cultural, socio-cultural, intercultural), and internal (ideological) plans that determine the content of vocational and pedagogical training of students on the basis of introduction theoretical and practical material characterized by multicultural orientation into the educational process. In accordance with such understanding of the multicultural component of vocational and pedagogical training, we can distinguish following main structural elements: ethnocultural; socio-cultural intercultural. The academic discipline «Theory and practice of formation of interethnic tolerance of future teachers of primary school» has been presented and its importance in multicultural preparation of masters students of specialty 013 «Primary education». It has been recommended innovative methods and forms of educational work that contribute to the preparation of a multicultural specialist in the elementary educational establishment. The author of the article has pointed the importance of pedagogical practice in multicultural training for future teachers of primary forms, independent and professionally directed extra-curricular work, students' research activity in the perspective of multicultural issues.

Key words: teacher of primary school, dialogue of cultures, culture of interethnic communication, interethnic tolerance, multicultural component, multicultural education, professional training, value orientations

Стаття надійшла до редакції 04.09.2018 p.

УДК 377.36:63-027.561

\section{ВІТАЛІЙ БАРБІНОВ}

Полтавський центр професійно-технічної освіти

\section{СТРУКТУРА ГОТОВНОСТІ МАЙБУТНІХ КВАЛІФІКОВАНИХ РОБІТНИКІВ АГРАРНОЇ ГАЛУЗІ ДО ПРОФЕСІЙНОЇ ДІЯЛЬНОСТІ}

у статті на основі аналізу наукових праць визначено поняття готовності майбутніх кваліфікованих робітників аграрної галузі до професійної діяльності. Готовність майбутніх кваліфікованих робітників аграрної галузі до професійної діяльності розглядається як складне утворення, що визначається єдністю та взаємообумовленістю таких структурних компонентів: мотиваційного, пізнавального, практичного, суб'єктного. Доведено, що результатом готовності майбутніх кваліфікованих робітників аграрної галузі до професійної діяльності $є$ здатність випускників професійно-технічних навчальних закладів успішно виконувати професійні обов'язки на ринку праці.

Ключові слова: готовність до професійної діяльності, кваліфіковані робітники аграрної галузі, професійно-технічний навчальний заклад, професійі знання, уміння, навички

Характерною ознакою сучасного розвитку аграрної галузі України є динамічне техніко-технологічне оновлення виробничих процесів, що грунтуються на знаннях, інноваціях, інтелектуальному і професійному потенціалах. Відтак, зростає потреба у фахівцях аграрної галузі зі сформованим професійним мисленням та 